\title{
Characteristics of interleukin-4 gene (C-589T, rs2243250) polymorphism in children with bronchial asthma and allergic rhinitis with isolated or allergic rhinitis-induced comorbid malocclusion
}

\author{
T. Ye. Shumna*A,C,D,E, O. S. Fedosieieva ${ }^{\mathrm{B}, \mathrm{C}, \mathrm{D}}$, T. P. Zinchenko ${ }^{\mathrm{B}, \mathrm{C}, \mathrm{D}}$, S. M. Nedelska ${ }^{\mathrm{F}}$, \\ 0. V. Voznyi ${ }^{\mathrm{F}}$, O. M. Kamyshnyic,F
}

Zaporizhzhia State Medical University, Ukraine

A - research concept and design; $\mathrm{B}$ - collection and/or assembly of data; C - data analysis and interpretation; D - writing the article; $\mathrm{E}$ - critical revision of the article; $\mathrm{F}$ - final approval of the article

Purpose. To determine the frequency of interleukin-4 (IL-4) (C-589T, rs2243250) single nucleotide polymorphism in children with bronchial asthma (BA) and allergic rhinitis (AR) and with isolated or allergic rhinitis-induced comorbid malocclusion.

Materials and methods. Single nucleotide polymorphism of the IL-4 (C-589T, rs2243250) gene was analyzed in 170 children aged between 6 and 17 years, 11 months, 29 days. Group I included 89 children with BA; Group II consisted of 31 children with AR; Group III was composed of 27 children with AR and distal occlusion (DO); Group IV comprised 23 children with malocclusion. Genotyping was performed using a commercial "SNP-express RT" kit by real-time polymerase chain reaction method (Applied Biosystems, USA) via TagMan ${ }^{\circledR}$ SNP Genotyping Assay on an amplifier CFX96 ${ }^{\mathrm{TM}}$ Real-Time PCR Detection System (Bio-Rad Laboratories, Inc., USA).

DNA was isolated using a commercial DNA-express kit ("LLC Research and Production Company LITEKH"). The general, recessive and dominant models of inheritance and the odds ratios with a $95 \%$ confidence interval were used for the analysis. The results analysis was conducted using the Statistica 6.0 RU licensed software package.

Results. IL-4 (C-589T, rs2243250) gene polymorphism in children with allergy and malocclusion living in Zaporizhzhia was analyzed for the first time.

The frequency of $\mathrm{C} / \mathrm{C}-\mathrm{C} / \mathrm{T}-\mathrm{T} / \mathrm{T}$ genotypes registration was $69.66 \%-22.47 \%-7.87 \%$ of cases in children with $\mathrm{BA} ; 58.06 \%-$ $38.71 \%-3.23 \%$ in children with AR; $62.96 \%-29.63 \%-7.40 \%$ in AR with DO. On the contrary, in children with malocclusion, the $\mathrm{C} / \mathrm{C}(34.78 \%)$ and $\mathrm{T} / \mathrm{T}(4.35 \%)$ genotypes were registered less frequently and the $\mathrm{C} / \mathrm{T}$ genotype $(60.87 \%)$ was recorded more often as a genetic feature of the DO phenotype.

Conclusions. The C/C genotype of IL-4 (C-589T, rs2243250) gene was associated with bronchial asthma (OR $=4.31 ; 95 \%$ $\mathrm{Cl}=1.63-11.36 ; \mathrm{P}=0.002)$ and allergic rhinitis $(\mathrm{OR}=4.32(95 \% \mathrm{Cl}=1.04-7.81 ; \mathrm{P}=0.04)$, in comparison with the fact that the $\mathrm{C} / \mathrm{T}+\mathrm{T} / \mathrm{T}$ genotype indicated a predisposition to malocclusion development.

Характеристика поліморфізму гена інтерлейкіну-4 (C-589T, rs2243250) у дітей із бронхіальною астмою, алергічним ринітом і з ортодонтичною патологією, яка ізольована чи коморбідна з алергічним ринітом

\section{Т. Є. Шумна, О. С. Федосєєва, Т. П. Зінченко, С. М. Недельська, О. В. Возний, О. М. Камишний}

Мета роботи - визначити частоту однонуклеотидного поліморфрізму гена інтерлейкіну-4 (IL-4) (C-589T, rs2243250) у дітей із бронхіальною астмою (БА), алергічним ринітом (АР) та з ортодонтичною патологією, що ізольована чи сформована на тлі алергічного риніту.

Матеріали та методи. Дослідження поліморфізму гена IL-4 (C-589T, rs2243250) виконали у 170 дітей віком від 6 до 17 років, 11 місяців, 29 днів. У I групу спостереження увійшли 89 дітей із БА; у II групу - 31 дитина з АР; у III групу - 27 дітей з AР і дистальним прикусом; у IV групу - 23 дитини з ортодонтичною патологією.

Генотипування здійснили методом полимеразної ланцюгової реакції «SNP-експрес-РB», використовуючи набори реагентів

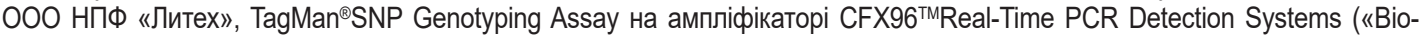
Rad Laboratories, Inc.», USA). Для аналізу використовували загальну, рецесивну та домінантну моделі успадкування та показники «відношення шансів» з 95 \% довірчим інтервалом. Результати опрацювали за допомогою ліцензійного пакета програми Statistica 6.0 RU.

Результати. Уперше в дітей із м. Запоріжжя з алергічною та ортодонтичною патологією дослідили поліморфізм гена IL-4 (C-589T, rs2243250). Частота реєстрації генотипів C/C - C/T - Т/Т становила в дітей із БА 69,66 \% - 22,47 \% - 7,87 \%; 3 АР - 58,06 \% - 38,71 \% - 3,23 \%; АР із дистальним прикусом - 62,96 \% - 29,63 \% - 7,40 \% випадків. У дітей з ортодонтичною патологією рідше реєстрували генотипи С/C (34,78 \%) та Т/T (4,35 \%), частіше - генотип С/T $(60,87 \%)$ як генетичну особливість фенотипу дистального прикусу.

Висновки. Генотип C/C гена IL-4 (C-589T, rs2243250) асоціювався з бронхіальною астмою (OR = 4,31; 95 \% Cl = 1,63-11.36; $\mathrm{p}=0,002)$ та алергічним ринітом (OR = 4,32; $95 \% \mathrm{Cl}=1,04-7,81 ; p=0,04)$, а генотипи C/T + Т/T свідчили про схильність до розвитку ортодонтичної патології.
Key words: gentic polymorphism, interleukin-4, bronchial asthma, allergic rhinitis, orthodontic pathology, children

Zaporozhye medical journa 2019; 21 (6), 723-732 DOI: 10.14739/2310-1210 2019.6.186484

*E-mail: tshumnaya72@ gmail.com

Ключові слова: генетичний поліморфізм, інтерлейкін-4, бронхіальна астма, алергічнй риніт, ортодонтична патологія, Аіти.

Запорізький медичний журнал. - 2019. T. 21, № 6(117). C. $723-732$ 
Ключевые слова: генетический полиморфизм, интерлейкин-4, бронхиальная астма, аммергический ринит, ортодонтическая патология, Аети.

Запорожский медицинский журнал. - 2019. T. 21, № 6(117). C. $723-732$

\title{
Характеристика полиморфизма гена интерлейкина-4 (C-589T, rs2243250) у детей с бронхиальной астмой, амергическим ринитом и с ортодонтической патологией, изолированной или коморбидной с аммергическим ринитом
}

\author{
Т. Е. Шумная, Е. С. Федосеева, Т. П. Зинченко, С. Н. Недельская, А. В. Возный, А. М. Камышный
}

Цель работы - определить частоту однонуклеотидного полиморфизма гена интерлейкина-4 (IL-4) (C-589T, rs2243250) у детей с бронхиальной астмой (БА), аллергическим ринитом (АР) и с ортодонтической патологией, изолированной или сформированной на фоне аллергического ринита.

Материалы и методы. Исследование полиморфизма гена IL-4 (C-589T, rs2243250) проведено у 170 детей в возрасте от 6 до 17 лет, 11 месяцев, 29 дней. В I группу наблюдения включены 89 детей с БА; во II группу - 31 ребенок с AP; в III группу - 27 детей с AP и дистальным прикусом; в IV группу - 23 ребенка с ортодонтической патологией. Генотипирование выполнили методом полимеразной цепной реакции «SNP-экспресс-PB» с использованием наборов реагентов ОOO НПФ «Литех», TagMan ${ }^{\circledR}$ SNP Genotyping Assay на амплификаторе CFX96 ${ }^{\text {TM}}$ Real-Time PCR Detection Systems («Bio-Rad Laboratories, Inc.», USA). Для анализа использовали общую, рецессивную и доминантную модели наследования и показатели «отношения шансов» с 95 \% доверительным интервалом. Анализ результатов проведен при помощи лицензионного пакета программы Statistica 6.0 RU.

Результаты. Впервые у детей г. Запорожья с аллергической и ортодонтической патологией исследован полиморфизм гена IL-4 (C-589T, rs2243250). Частота регистрации генотипов C/C - C/T - T/T составила у детей с БА 69,66 \% - 22,47 \% 7,87 \%; с АР - 58,06 \% - 38,71 \% - 3,23 \%; АР с дистальным прикусом - 62,96 \% - 29,63 \% - 7,4 \% случаев. У детей с ортодонтической патологией реже регистрировали генотипы C/C (34,78 \%) и Т/T (4,35 \%), чаще - генотип С/T $(60,87$ \%) как генетическую особенность фенотипа дистального прикуса.

Выводы. Генотип C/C гена интерлейкина-4 (C-589T, rs2243250) ассоциировался с бронхиальной астмой (OR $=4,31$; $95 \% \mathrm{Cl}=1,63-11,36 ; p=0,002)$ и аллергическим ринитом (OR = 4,32 (95\% Cl = 1,04-7,81; $\mathrm{p}=0,04)$, а генотип C/T + T/T свидетельствовал о предрасположенности к развитию ортодонтической патологии.

\section{Introduction}

The morbidity rate of allergic diseases has shown a continuous increase in Europe and in other regions of the world, that currently poses a serious challenge to modern pediatrics and requires further research [1]. Thus, the well-known population-based studies indicate that the frequency of allergic diseases just in teenagers fluctuates from $40.3 \%$ to $71.1 \%$. The prevalence of bronchial asthma (BA) is $12.9 \%$ and allergic rhinitis (AR) $-32.8 \%$ [2,3]. In Germany, rhinitis was comorbidity of BA in $34.7 \%$ of children, and in Barcelona (Spain), AR was combined with BA in $49.5 \%$ of cases [4,5].

At the same time, in conditions of a high prevalence rate of malocclusion in children and adolescents, various dental anomalies and deformities represent up to 56.13-62.48 \%, and in cases of nasopharyngeal diseases, including rhinitis, this figure increases to $86.08 \pm 1.59 \%$. However, the frequency of malocclusion without concomitant pathology is much less and rates to $35.63-45.92 \%$ of cases, which necessitates the study of isolated malocclusion and with AR comorbidity in children $[6,7]$.

Allergic diseases and malocclusion, often combined with AR and coexisted with nasal obstruction or without it, are considered as a multifactorial diseases associated with single nucleotide polymorphism of genes. These diseases are manifested only in interaction between genetic aspects of pathology and environmental factors, a combined effect of which leads to the disease development and phenotypic changes. Nowadays, there is the theory that allergic diseases are caused by a violation of immune system regulation due to activation of CD4+ T helper type 2 lymphocytes and increased secretion of cytokines, including anti-inflammatory interleukin-4 (IL-4), which contributes to IgE synthesis, mast cells and eosinophils activation. As a result, allergic inflammation develops and secretion of other immunoglobulins is activated forming the humoral immune response [8].
The IL-4 gene is located on chromosome $5 \mathrm{q} 31$. More than 50 allelic variants of the IL-4 gene polymorphisms have been identified including rs2243250 (S589T) which is the most significant genetic polymorphism observed in the promoter site and characterized by the replacement of cytosine $(\mathrm{C})$ with thymine $(\mathrm{T})$. That is, single nucleotide polymorphism (SNP) in the coding region of the IL-4 receptor (IL-4R) C589T (rs2243250) determines the presence of $C$ versus $T$ at position 589 in the amino acid sequence. It has been studied that the T allele of IL-4 rs2243250 polymorphism can increase binding of nuclear transcription factors to the promoter region of the IL- 4 gene, and thus this polymorphism is functionally important. IL-4R transmits signals into the cellular nucleus exerting biological functions and playing an important role in regulating not only IL-4 synthesis, but also estrogenes, and influencing bone remodeling [8-10].

This work should confirm or disprove the hypothesis that the IL-4 (C-589T, rs2243250) gene polymorphism, which results in the replacement of $\mathrm{C}$ with $\mathrm{T}$ at position 589 in the cytoplasmic domain of the mature protein, is associated with allergic diseases and more often recorded in children with BA and / or AR than in children with distal occlusion (DO) without allergic diseases.

\section{Purpose}

To determine the frequency of interleukin-4 (IL-4) (C-589T, rs2243250) SNP in children with respiratory forms of allergic diseases (BA and AR) and with isolated or AR-induced comorbid malocclusion.

\section{Materials and methods}

SNP of the IL-4 (C-589T, rs2243250) gene was analyzed in 170 children aged between 6 and 17 years, 11 months, 
29 days. To confirm or disprove the hypothesis of genetic predisposition and association of the studied gene polymorphism with certain respiratory forms of allergic pathology and to clarify the causes of its comorbidity with AR or isolated malocclusion, 89 children with BA were included in Group 1; Group 2 consisted of 31 children with AR; Group III was composed of 27 children with AR and DO; Group IV comprised 23 children with DO without allergic pathology.

The inclusion criteria for enrolment into the study were diagnosed $\mathrm{BA}, \mathrm{AR}, \mathrm{AR}$ combined with $\mathrm{DO}$, isolated $\mathrm{DO}$; duration of allergic pathology 2 years or more; the absence of chronic pathology in the stage of decompensation. Exclusion criteria were acute infectious diseases; severe concomitant somatic and psychiatric pathology, congenital or acquired heart defects, malignant tumors; refusal of the patient and / or parents to participate in the study. Prior to starting the work, the children and their parents were timely informed of the study purpose, tasks, methods and gave written informed consent to participate in the study.

The IL-4 gene (C-589T, rs2243250) polymorphism was genotyped using a commercial "SNP-express RT" kit by real-time polymerase chain reaction (RT-PCR) according to the manufacturer's instruction (Applied Biosystems, USA). Genomic DNA was extracted from the whole venous blood of children using reagent kits ("LLC Research and Production Company LITEKH"), TagMan ${ }^{\circledR}$ SNP Genotyping Assay on the amplifier CFX96 ${ }^{\mathrm{TM}}$ Real-Time PCR Detection Systems (Bio-Rad Laboratories, Inc., USA) at the Department of Molecular Genetic Studies of the Educational Medical and Laboratory Center at the Department of Microbiology, Virology and Immunology, Zaporizhzhia State Medical University, Zaporizhzhia (under the guidance of the Head of the Department of Microbiology, Virology and Immunology MD, PhD, DSc, Professor O. M. Kamyshnyi). The $x^{2}$ method $(\alpha=0.05, d f=1)$ was used to test whether the control sample distribution was in accordance with the Hardy-Weinberg equilibrium. To identify the association between the disease and the IL-4 gene (C-589T, rs2243250) polymorphism, the general, recessive and dominant inheritance models and odds ratio (OR) with a $95 \%$ confidence interval (95\% $\mathrm{Cl}$ ) were used. The data obtained as a result of the study were processed using nonparametric methods of statistical analysis with the Statistica 6.0 RU software package.

\section{Results}

In the work presented, we analyzed the distribution of polymorphism genotypes of the IL-4 (S-589T, rs2243250) gene in each study group depending on the nosology, namely, the presence of allergic pathology: BA, AR, comorbid $D O$ induced by nasal obstruction due to $A R$ and isolated malocclusion in the form of DO without allergic diseases.

Thus, in children of Group 1 with BA, the homozygous C/C genotype of the IL-4 (C-589T, rs2243250) gene polymorphism was prevalent and recorded in $69.66 \%$. Accordingly, the homozygous variant $\mathrm{T} / \mathrm{T}$ and heterozygous C/T were significantly less frequent, in $7.87 \%$ and $22.47 \%$ of cases, respectively. These data are presented in Fig. 1.

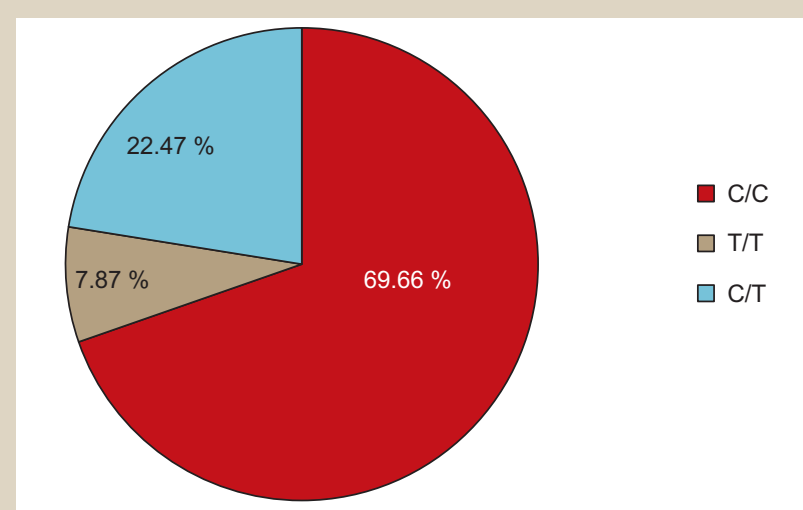

Fig. 1. Distribution of IL-4 (C-589T, rs2243250) gene polymorphism in BA children.

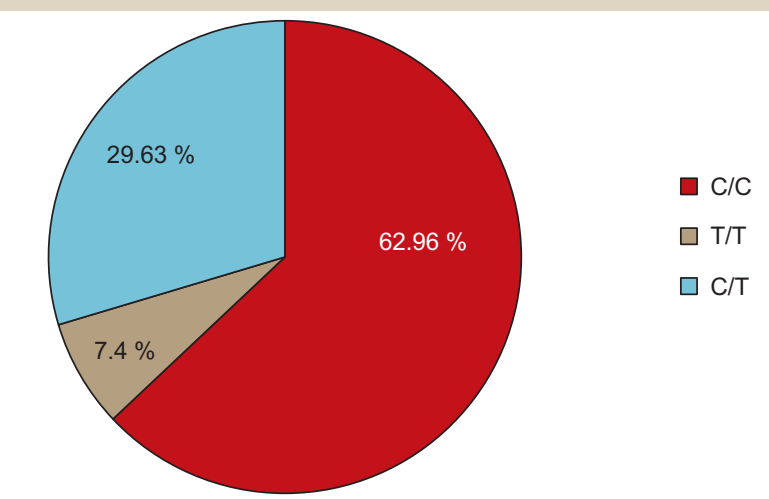

Fig. 3. Distribution of IL-4 (C-589T, rs2243250) gene polymorphism in children with AR and DO.

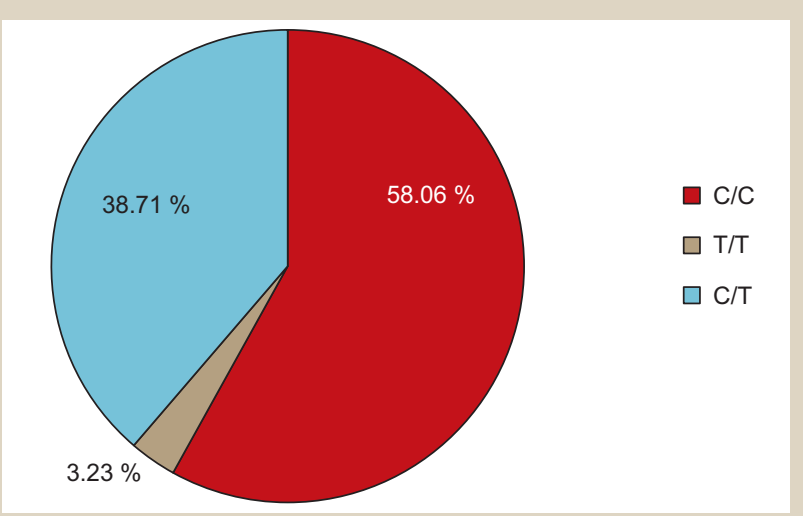

Fig. 2. Distribution of IL-4 (C-589T, rs2243250) gene polymorphism in AR children

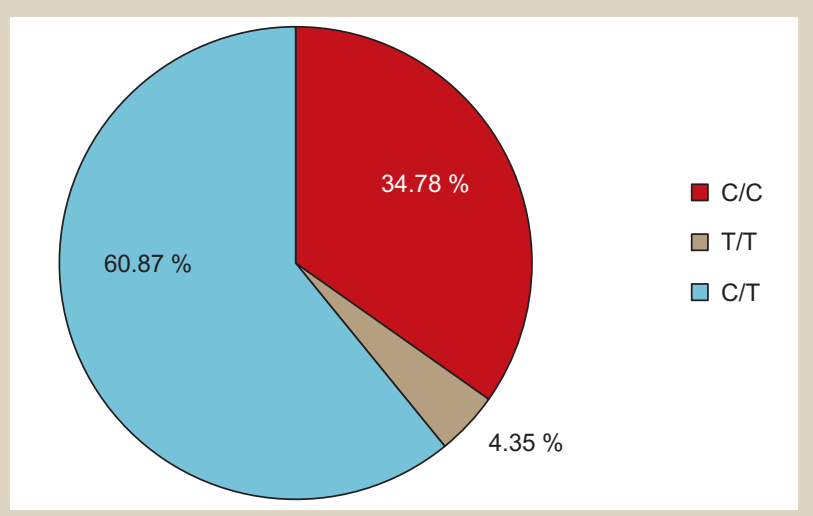

Fig. 4. Distribution of IL-4 (C-589T, rs2243250) gene polymorphism in children with DO 


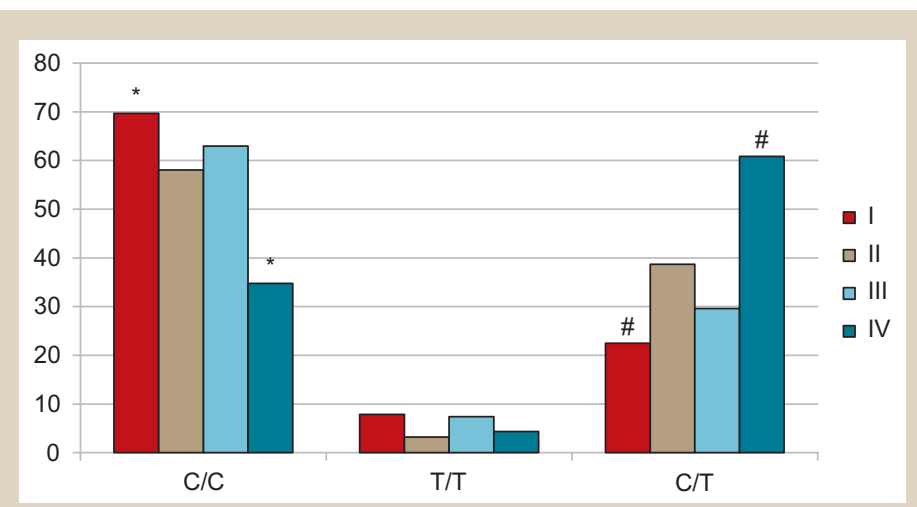

Fig. 5. Distribution of IL-4 (C-589T, rs2243250) gene polymorphism in the examined children.

*: $P<0.05$ - the difference is significant between the $C / C$ genotype frequency in Group 1 and 4; \#: $P<0.05$ - the difference is significant between the $C / T$ genotype frequency in Group 1 and 4$)$.

Table 1. Distribution of IL-4 (C-589T, rs2243250) gene polymorphism in the examined children according to the general inheritance model (chi-square test, $\mathrm{df}=2$ )

\begin{tabular}{|c|c|c|c|}
\hline Groups (n) & Genotype C/C & Genotype C/T & Genotype T/T \\
\hline $1(n=89)$ & 0.697 & 0.225 & 0.079 \\
\hline $2(n=31)$ & 0.581 & 0.387 & 0.032 \\
\hline $3(n=27)$ & 0.630 & 0.296 & 0.074 \\
\hline $4(n=23)$ & 0.348 & 0.609 & 0.043 \\
\hline \multirow[t]{2}{*}{$1-2$} & $X^{2}=0.48, P=0.18$ & & \\
\hline & $\begin{array}{l}\mathrm{OR}=1.66 \\
95 \% \mathrm{Cl}[0.71-3.86]\end{array}$ & $\begin{array}{l}\mathrm{OR}=0.46 ; \\
95 \% \mathrm{Cl}[0.19-1.10]\end{array}$ & $\begin{array}{l}\mathrm{OR}=2.56 ; \\
95 \% \text { Cl [0.30-21.69] }\end{array}$ \\
\hline \multirow[t]{2}{*}{$1-3$} & $X^{2}=0.58, P=0.75$ & & \\
\hline & $\begin{array}{l}\mathrm{OR}=1.35 \\
95 \% \mathrm{Cl}[0.55-3.33]\end{array}$ & $\begin{array}{l}\mathrm{OR}=0.69 ; 95 \% \mathrm{Cl} \\
{[0.26-1.81]}\end{array}$ & $\begin{array}{l}\mathrm{OR}=1.07 ; 95 \% \mathrm{Cl} \\
{[0.21-5.47]}\end{array}$ \\
\hline \multirow[t]{2}{*}{$1-4$} & $X^{2}=12.75, P=0.002$ & & \\
\hline & $\begin{array}{l}\mathrm{OR}=4.31 ; 95 \% \mathrm{Cl} \\
{[1.63-11.36]}\end{array}$ & $\begin{array}{l}\mathrm{OR}=0.19 ; 95 \% \mathrm{Cl} \\
{[0.07-0.49]}\end{array}$ & $\begin{array}{l}\mathrm{OR}=1.88 ; 95 \% \mathrm{Cl} \\
{[0.22-16.08]}\end{array}$ \\
\hline \multirow[t]{2}{*}{$2-3$} & $X^{2}=0.89, P=0.64$ & & \\
\hline & $\begin{array}{l}\mathrm{OR}=0.81 \\
95 \% \mathrm{Cl}[0.28-2.35]\end{array}$ & $\begin{array}{l}\mathrm{OR}=1.50 \\
95 \% \text { CI [0.50-4.50] }\end{array}$ & $\begin{array}{l}\mathrm{OR}=0.42 \\
95 \% \mathrm{Cl}[0.04-4.87]\end{array}$ \\
\hline \multirow[t]{2}{*}{$2-4$} & $X^{2}=2.88, P=0.24$ & & \\
\hline & $\begin{array}{l}\mathrm{OR}=2.60 \\
95 \% \mathrm{Cl}[0.85-7.92]\end{array}$ & $\begin{array}{l}\mathrm{OR}=0.41 \\
95 \% \mathrm{Cl}[0.13-1.23]\end{array}$ & $\begin{array}{l}\mathrm{OR}=0.73 \\
95 \% \text { Cl [0.04-12.38] }\end{array}$ \\
\hline \multirow[t]{2}{*}{$3-4$} & $X^{2}=4.92, P=0.09$ & & \\
\hline & $\begin{array}{l}\mathrm{OR}=3.19 ; \\
95 \% \mathrm{Cl}[1.00-10.17]\end{array}$ & $\begin{array}{l}\mathrm{OR}=0.27 \\
95 \% \mathrm{Cl}[0.08-0.88]\end{array}$ & $\begin{array}{l}\mathrm{OR}=1.76 ; \\
95 \% \mathrm{Cl}[0.15-20.76]\end{array}$ \\
\hline
\end{tabular}

Table 2. Distribution of IL-4 (C-589T, rs2243250) gene polymorphism in the examined children according to the general inheritance model (chi-square test, $\mathrm{df}=2$ )

\begin{tabular}{|c|c|c|c|}
\hline Groups (n) & Genotype C/C & Genotype C/T & Genotype T/T \\
\hline $\mathrm{BA}(\mathrm{n}=89)$ & 0.697 & 0.225 & 0.079 \\
\hline $\operatorname{AR}(n=58)$ & 0.603 & 0.345 & 0.052 \\
\hline $\mathrm{DO}(\mathrm{n}=23)$ & 0.348 & 0.609 & 0.043 \\
\hline \multirow[t]{2}{*}{$B A-A R$} & $X^{2}=2.70, P=0.26$ & & \\
\hline & $\begin{array}{l}\mathrm{OR}=1.51 ; 95 \% \mathrm{Cl} \\
{[0.75-3.02]}\end{array}$ & $\begin{array}{l}\mathrm{OR}=0.55 ; 95 \% \mathrm{Cl} \\
{[0.26-1.15]}\end{array}$ & $\begin{array}{l}\mathrm{OR}=1.57 ; 95 \% \mathrm{Cl} \\
{[0.39-6.31]}\end{array}$ \\
\hline \multirow[t]{2}{*}{ BA - DO } & $X^{2}=12.75, P=0.002$ & & \\
\hline & $\begin{array}{l}\mathrm{OR}=4.31 ; 95 \% \mathrm{Cl} \\
{[1.63-11.36]}\end{array}$ & $\begin{array}{l}\mathrm{OR}=0.19 ; 95 \% \mathrm{Cl} \\
{[0.07-0.49]}\end{array}$ & $\begin{array}{l}\mathrm{OR}=1.88 ; 95 \% \mathrm{Cl} \\
{[0.22-16.08]}\end{array}$ \\
\hline \multirow[t]{2}{*}{$A R-D O$} & $X^{2}=4.78, P=0.09$ & & \\
\hline & $\begin{array}{l}\mathrm{OR}=2.85 ; 95 \% \mathrm{Cl} \\
{[1.04-7.81]}\end{array}$ & $\begin{array}{l}\mathrm{OR}=0.34 ; 95 \% \mathrm{Cl} \\
{[0.12-0.92]}\end{array}$ & $\begin{array}{l}\mathrm{OR}=1.20 ; 95 \% \mathrm{Cl} \\
{[0.12-12.17]}\end{array}$ \\
\hline
\end{tabular}

In children of Group 2 with AR, the homozygous C/C genotype also dominated and it was registered in more than half of children (58.06\%). A bit more than one third of these children (38.71\%) showed the heterozygous $\mathrm{C} / \mathrm{T}$ variant of the IL-4 (C-589T, rs2243250) gene polymorphism, and the homozygous $\mathrm{T} / \mathrm{T}$ variant was detected only in $3.23 \%$ of cases, as shown in Fig. 2.

In children included in Group 3 with AR and DO as in the previous groups, the $\mathrm{C} / \mathrm{C}$ and $\mathrm{C} / \mathrm{T}$ variants of the IL-4 (C-589T, rs2243250) gene polymorphism prevailed representing $62.96 \%$ and $29.63 \%$ of children, respectively. In this case, the $\mathrm{T} / \mathrm{T}$ genotype was registered only in $7.40 \%$. These data are shown in Fig. 3.

In children of Group 4 without allergic pathology and only with isolated $\mathrm{DO}$, the homozygous $\mathrm{T} / \mathrm{T}$ genotype was found only in $4.35 \%$ of children with DO (Fig. 4). Conversely, unlike previous examined groups, the heterozygous $\mathrm{C} / \mathrm{T}$ genotype was dominant and recorded in $60.87 \%$ of patients only with malocclusion, but significantly more often than in BA children (14/23 vs. $20 / 89$, Yates corrected Chisquare $=10.99, P=0.0009$ ). The homozygous $C / C$ variant was registered in $34.78 \%$ of patients with malocclusion, significantly less than in BA children ( $8 / 23$ vs. $62 / 89$, Yates corrected Chi-square $=8.06, P=0.0045)$. The comparative characteristic of each genotype frequency in IL-4 (C-589T, rs2243250) gene polymorphism depending on the presence or absence of BA, AR, AR with DO or only malocclusion in the examined children is presented in Fig. 5.

Further, the general inheritance model was used to study a genetic predisposition based on the presence or absence of associations between the IL-4 (C-589T, rs2243250) gene polymorphism and multifactorial allergic diseases development (BA, AR), AR combined with DO or only DO without an allergic pathology after testing the samples to detect the Hardy-Weinberg equilibrium (Table 1).

The data presented above refuted our hypothesis concerning $\mathrm{C}$ with $\mathrm{T}(\mathrm{C}-589 \mathrm{~T})$ replacement. It can be seen that the $\mathrm{C} / \mathrm{C}$ genotype was associated with $\mathrm{BA}$ development $\left(\mathrm{OR}=4.31 ; 95 \% \mathrm{Cl}\right.$ [1.63-11.36], $\mathrm{X}^{2}=12.75, \mathrm{P}=0.002$ and there was a tendency to $\mathrm{C} / \mathrm{C}$ genotype predominance in children with AR and comorbid DO unlike in children without allergy but with malocclusion $(\mathrm{OR}=3.19,95 \% \mathrm{Cl}$ [1.00-10.17], $X^{2}=4.92, P=0.09$.

Taking into account that there were not significant differences in the distribution of the IL-4 (C-589T, rs2243250) gene polymorphism between children in Group 2 and 3 (with $A R$ and $A R$ with $D O$ ), therefore these children were grouped together as patients with AR. The analysis of genotypes distribution between groups of children with BA, AR and DO was repeated (Table 2).

However, these data were consistent with the findings that the C/C genotype of the IL-4 (C-589T, rs2243250) gene polymorphism was significantly prevalent in $\mathrm{BA}$ children (OR $=4.31 ; 95 \% \mathrm{Cl}$ [1.63-11.36], $\mathrm{X}^{2}=12.75, \mathrm{P}=0.002$ (actual) and in all children with both AR and AR with malocclusion comorbidity $(\mathrm{OR}=2.85 ; 95 \% \mathrm{Cl}$ [1.04-10.17], $X^{2}=4.78 ; P=0.09$ (as the tendency) compared to the group of children with DO without allergic pathology.

Therefore, in order to clarify an association between the genotype and allergic pathology or malocclusion development in the examined children, the recessive and dominant inheritance models (Tables 3-6) were also analyzed. 
Table 3. Recessive inheritance model of the IL-4 (C-589T, rs2243250) gene polymorphism in children with BA and DO (chi-square test, $\mathrm{df}=1$ )

\begin{tabular}{|c|c|c|c|c|c|c|}
\hline \multirow{2}{*}{ Genotypes } & BA & DO & \multirow[t]{2}{*}{$x^{2}$} & \multirow[t]{2}{*}{$P$} & \multicolumn{2}{|l|}{ OR } \\
\hline & $n=89$ & $n=23$ & & & \begin{tabular}{|l|} 
value \\
\end{tabular} & $95 \% \mathrm{Cl}$ \\
\hline Genotype C/C & 0.697 & 0.348 & \multirow[t]{2}{*}{9.49} & \multirow[t]{2}{*}{0.002} & 4.31 & $1.63-11.36$ \\
\hline Genotype $\mathrm{C} / \mathrm{T}+\mathrm{T} / \mathrm{T}$ & 0.303 & 0.652 & & & 0.23 & $0.09-0.61$ \\
\hline
\end{tabular}

Table 4. Dominant inheritance model of the IL-4 (C-589T, rs2243250) gene polymorphism in children with BA and DO (chi-square test, df $=1$ )

\begin{tabular}{|c|c|c|c|c|c|c|}
\hline \multirow{2}{*}{ Genotypes } & DO & BA & \multirow{2}{*}{$x^{2}$} & \multirow[t]{2}{*}{$P$} & \multicolumn{2}{|l|}{ OR } \\
\hline & $n=23$ & $n=89$ & & & \begin{tabular}{|l} 
value \\
\end{tabular} & $95 \% \mathrm{Cl}$ \\
\hline Genotype C/C & 0.348 & 0.697 & \multirow[t]{2}{*}{9.49} & \multirow[t]{2}{*}{0.002} & 0.23 & $0.09-0.61$ \\
\hline Genotype $\mathrm{C} / \mathrm{T}+\mathrm{T} / \mathrm{T}$ & 0.652 & 0.303 & & & 4.31 & $1.63-11.36$ \\
\hline
\end{tabular}

Table 5. Recessive inheritance model of the IL-4 (C-589T, rs2243250) gene polymorphism in children with AR and DO (chi-square test, df $=1$ )

\begin{tabular}{|c|c|c|c|c|c|c|}
\hline \multirow[t]{2}{*}{ Genotypes } & \multirow{2}{*}{\begin{tabular}{|l} 
AR \\
$n=58$
\end{tabular}} & \multirow{2}{*}{\begin{tabular}{|l} 
DO \\
$n=23$
\end{tabular}} & \multirow[t]{2}{*}{$x^{2}$} & \multirow[t]{2}{*}{$\mathbf{P}$} & \multicolumn{2}{|l|}{ OR } \\
\hline & & & & & value & $95 \% \mathrm{Cl}$ \\
\hline Genotype C/C & 0.603 & 0.348 & \multirow[t]{2}{*}{4.32} & \multirow[t]{2}{*}{0.04} & 2.85 & $1.04-7.81$ \\
\hline Genotype $\mathrm{C} / \mathrm{T}+\mathrm{T} / \mathrm{T}$ & 0.397 & 0.652 & & & 0.35 & $0.13-0.96$ \\
\hline
\end{tabular}

Table 6. Dominant inheritance model of the IL-4 (C-589T, rs2243250) gene polymorphism in children with AR and DO (chi-squared test, $\mathrm{df}=1)$

\begin{tabular}{|c|c|c|c|c|c|c|}
\hline \multirow{2}{*}{ Genotypes } & DO & AR & \multirow{2}{*}{$x^{2}$} & \multirow[t]{2}{*}{$\mathbf{P}$} & \multicolumn{2}{|l|}{ OR } \\
\hline & $n=23$ & $n=58$ & & & \begin{tabular}{|l|} 
value \\
\end{tabular} & $95 \% \mathrm{Cl}$ \\
\hline $\mathrm{C} / \mathrm{C}$ genotype & 0.348 & 0.603 & 4.32 & 0.04 & 0.35 & $0.13-0.96$ \\
\hline $\mathrm{C} / \mathrm{T}+\mathrm{T} / \mathrm{T}$ genotype & 0.652 & 0.397 & & & 2.85 & $1.04-7.81$ \\
\hline
\end{tabular}

While analyzing the study results, it was considered that children with the C/C genotype of the IL-4 (C-589T, rs2243250) gene polymorphism had a relative risk of developing BA at any time of life. In addition, DO predisposition as an isolated malocclusion $(P=0.002)$ with $O R=4.31(95 \%$ $\mathrm{Cl}=1.63-11.36)$ was noted in children with the $\mathrm{C} / \mathrm{T}+\mathrm{T} / \mathrm{T}$ genotype.

These data also identified an association between a relatively high risk of developing malocclusion in children $(P=0.04)$ OR $=4.32(95 \% \mathrm{Cl}=1.04-7.81)$ and both the $\mathrm{C} / \mathrm{C}$ genotype, as a potential marker of $A R$, and the $\mathrm{C} / \mathrm{T}$ $+\mathrm{T} / \mathrm{T}$ genotype of the IL-4 (C-589T, rs2243250) gene polymorphism.

Therefore, summarizing the results of the conducted study, it can be stated that allergic pathology such as BA and $A R$ in children was associated with the $\mathrm{C} / \mathrm{C}$ genotype $(69.7 \%$ and $60.3 \%$ ) while malocclusion - with the $\mathrm{C} / \mathrm{T}+\mathrm{T} / \mathrm{T}$ genotype $(65.2 \%)$ of the IL-4 (C-589T, rs2243250) gene polymorphism. Therefore, it can be assumed that children with the $\mathrm{C} / \mathrm{C}$ genotype had DO with comorbid AR induced by nasal obstruction of allergic genesis, and malocclusion was formed initially in children with the $\mathrm{C} / \mathrm{T}+\mathrm{T} / \mathrm{T}$ genotype.

\section{Discussion}

Then, we compared and presented in Fig. 6 our data on the IL-4 (C-589T, rs2243250) gene polymorphism distribution in each study group with known widely varied data of population studies [11].

So, the comparison of genotype frequencies between the examined children of Zaporizhzhia (ZP) and children from Europe (EUR), South Asian (SAS), Admixed Ame- rican (AMR), East Asian (EAS), Africa (AFR), Colombians from Medellin, Colombia (SLM), Finland (FIN), showed that the $\mathrm{C} / \mathrm{C}-\mathrm{C} / \mathrm{T}-\mathrm{T} / \mathrm{T}$ genotype frequencies in children of Zaporizhzhia with BA $(69.66 \%-22.47 \%-7.87 \%)$, AR $(58.06 \%-38.71 \%-3.23 \%)$ and AR comorbid with DO $(62.96 \%-29.63 \%-7.40 \%)$ were almost matched the frequency in Europe $(70.2 \%-26.0 \%-3.8 \%)$ and South Asian $(68.1 \%-27.0 \%-4.9 \%)$. At the same time, the $\mathrm{C} / \mathrm{C}-\mathrm{T} / \mathrm{T}-\mathrm{T} / \mathrm{T}$ genotype frequencies in children from Zaporizhzhia with malocclusion $(34.78 \%-60.87 \%-$ $4.35 \%$ ) partially matched those in Colombians from Medellin, Colombia $(39.4 \%-50.0 \%-10.6 \%)$ and Finland (41.4\% - 48.5\% - 10.1\%).

The genotyping performed for all the examined children generally showed that the homozygous C/C genotype, registered in $61.76 \%(105 / 170)$ cases, was the dominant one. The heterozygous $\mathrm{C} / \mathrm{T}$ and the homozygous $\mathrm{T} / \mathrm{T}$ genotypes were less common, in $31.76 \%$ (54/170) and $6.44 \%(11 / 170)$ of children, respectively. Meanwhile, our data matched the indicators in Europe and South Asian, as the $\mathrm{C} / \mathrm{C}, \mathrm{C} / \mathrm{T}$ and $\mathrm{T} / \mathrm{T}$ genotype frequencies were $70.2 \%$ and $68.1 \%, 26.0 \%$ and $27.0 \%, 3.8 \%$ and $4.9 \%$ of cases, respectively, in these populations (Fig. 7). A large variability in the incidence rate of C/C-C/T-T/T genotypes of the IL-4 (C-589T, rs2243250) gene polymorphism was noted among the populations of Admixed American (42.1\% - $42.7 \%$ $15.3 \%)$, East Asian (4.2 \% - 35.9 \% - $59.9 \%)$, Africa $(7.6 \%-38.9 \%-53.6 \%)$ [11].

These data show that hereditary features of immunopathogenesis can be found in different population groups, which are of both theoretical and practical interest for further study. 


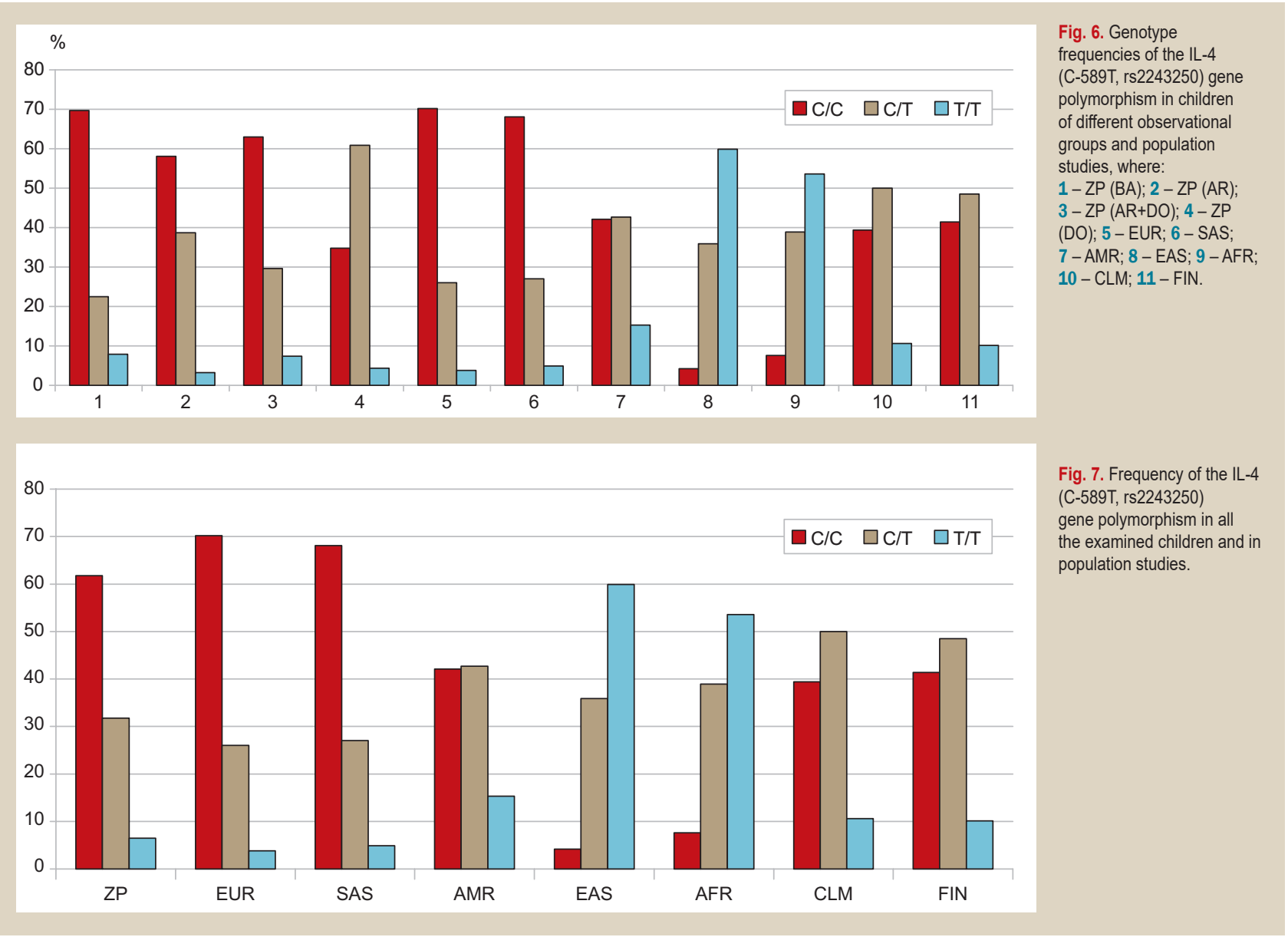

It is worth mentioning that we have obtained study results different from our initial hypothesis. Further analysis of information related to this problem has shown all its complexity focusing on issues to study SNP located in the promoter region of the IL-4 gene (C-589T, rs2243250) and determining $\mathrm{C}$ versus $\mathrm{T}$ presence in different positions of amino acid sequence as well as in relation to other chromosomal regions and segments.

Thus, according to V. B. Ivanova, in children with atopic BA living in Krasnoyarsk, SNP C-590 T of the IL-4 gene (rs2243250) was genotyped. As a result, the homozygous $\mathrm{C} / \mathrm{C}$ and $\mathrm{T} / \mathrm{T}$ variants were recorded in $52.38 \%$ and $6.67 \%$ of cases, respectively, while the heterozygous $\mathrm{C} / \mathrm{T}$ variant was found in $42.38 \%$ of patients, that is, almost two times more frequently than in our study. However, this study also showed that the T/T genotype frequency was $9.2 \%$ in the group of patients with uncontrolled BA and it was higher than in children with controlled BA (3.9\%) [12].

Nevertheless, in the genotypes of other populations, for example, the Mauritian Indian and Chinese Han populations, there was no significant association between C-590 T of the IL-4 gene and BA development as well as no significant differences were observed when comparing these groups based on distribution of polymorphisms IL-4 $-590 \mathrm{C} / \mathrm{T}$ [13].

At the same time, it is known that in Brazilian adolescents with allergic pathology and sensitization to domestic allergens, the $\mathrm{C} / \mathrm{T}$ and $\mathrm{T} / \mathrm{T}$ genotypes of IL-4-590 rs2243250 were recorded in $10.2 \%$ and $42.9 \%$ of cases, respec- tively, against $43.1 \%$ and $13.8 \%$ in healthy children [2]. Gurieva L. L. also believes that a biological marker for a high risk of developing atopic $B A$ without associated allergic diseases is the T allele of the SNP C-590> T in the IL-4 gene (OR = 1.59; $\mathrm{Cl} 95 \%$ = 1.02-2.48) [14].

But in the studies of Smolnikova M. V. et al., as well as in our study, it was shown that the C/C genotype of IL-4 (rs2243250; rs2070874) can be a genetic marker for risk of developing both controlled (RR 0.26; SE 0.38; $P=0.0008$ ) and uncontrolled (RR 0.3; SE 0.38; $P=0.0018$ ) atopic asthma [15].

The children with infectious-dependent BA were more likely to have the heterozygous C/T genotype of the IL-4 (C-589T) gene constituting $54.05 \%$. In addition, this genotype was a predictor of severe infectious-dependent BA, resistant to anti-inflammatory therapy [16].

Furthermore, E. A. Khotko and A. D. Taganovych presented a detailed analysis of reference data on the role of gene polymorphism, including the IL-4 gene, responsible for the production of pathogenetically important proteins in immunocompetent cells of patients with chronic obstructive pulmonary diseases [17]. There are also data evidencing a greater susceptibility to the risk of developing chronic obstructive pulmonary diseases in individuals, IL-4 - 589T allele carriers, from the Kazakh population [18].

Under industrial pollution conditions, genotyping of IL-4 - C-589T (rs2243250) SNP among adult patients with occupational BA, asbestosis, and occupational chronic obstructive pulmonary disease revealed that $56.4 \%$ of patients 
with occupational asthma had homozygous $\mathrm{T} / \mathrm{T}$ variant of the IL-4 gene in the presence of concomitant infection of the nasopharynx, neutrophilic inflammation and destructive radiographic changes. This allowed scientists to suggest that the homozygous genotype T/T of the SNP C-589T of the IL-4 gene presence contributes to a long-term circulation of pro-inflammatory cytokines elevated levels. This, in turn, leads not only to destructive processes in the lungs progression, but also to chronic inflammation confirming the association between IL-4 T allele and an inflammatory process activation and maintenance. The association between the $T$ allele of the IL-4 as well as an increased level of systemic inflammatory markers and a higher degree of respiratory failure was also detected in workers exposed to industrial aerosols. Thus, in asbestosis, the presence of T allele IL-4 increased the risk of developing II-III degree respiratory failure by 5.2 times $(\mathrm{OR}=5.217,95 \% \mathrm{Cl}=1.115-24.407$ ). Therefore, the IL-4 C589T (rs2243250) gene polymorphism identification allowed to identify the risk groups for more severe forms of occupational bronchopulmonary diseases development [19].

There are slightly less studies of the IL-4 gene polymorphism in patients with AR. Thus, when studying SNPs of the IL-4 (rs2243248, rs2243250 and rs2070874) in 98 patients with $A R$, it was found that $C / C$ genotype in (rs2070874) was significantly correlated with AR development, and SNPs of the IL-4 could change the clinical picture of the disease [20].

In Poland, Barbara Korzycka-Zaborowska with colleagues showed that the $(590 \mathrm{C} / \mathrm{T}) \mathrm{IL}-4$ gene polymorphism was associated with $A R$ in $15.3 \%$ of patients, compared with $5.8 \%$ of examined controls without $A R, X^{2}=4.368 ; P<0.05$ [21]. In a study of other scientists, the risk of developing AR was associated with the IL-4 gene -590 TT genotype $[O R=1.93,95 \% \mathrm{Cl}(1.61-2.31), \mathrm{P}=0.00]$ and the TT+TC unlike CC genotype of IL-4 C-33/T polymorphism was significantly associated with allergic diseases $[\mathrm{OR}=3.23$, $95 \% \mathrm{Cl}$ (1.13-9.25), $\mathrm{P}=0.03$ ] [22].

In Pakistan, genotyping for SNP IL-4 C-589T (rs2243250), T + 2979G (rs2227284) and C-33T (rs2070874) was performed in 108 patients with BA and 106 with AR. Although we studied SNP C-589T (rs2243250) of the IL-4 gene, but unlike our results, S. Micheal and colleagues showed that $\mathrm{C} / \mathrm{C}$ genotype was recorded in $24.1 \%$ of $\mathrm{BA}$ patients, $\mathrm{C} / \mathrm{T}$ - in $58.3 \%$ and $\mathrm{T} / \mathrm{T}$ - in $17.6 \%$. Concurrently, in children with allergic rhinitis, the $\mathrm{C} / \mathrm{C}$ genotype was detected in $17 \%$ of cases; C/T - in $58.5 \%$; T/T - in $24.55 \%$. Therefore, SNP C-589T (rs2243250) of the IL-4 was significantly associated with both $B A\left(X^{2}=11.0 ; P=0.004\right)$ and $A R\left(X^{2}=20.2 ; P<0.001\right)$. In addition, the polymorphism $\mathrm{T}+2979 \mathrm{G}$ (rs2227284) of the IL-4 gene was also related to genetic risk factors for the developing asthma and AR in Pakistan. But, unlike previous studies, there were no significant differences between the groups of patients with both $B A$ and $A R$ and the control group when studying the SNP C-33T (rs2070874) of the IL-4 gene [23].

We have not found data regarding the polymorphism (C-589T, rs2243250) of the IL-4 gene detection in children with malocclusion in the scientific literature available today. Nevertheless, E. Sh. Hryhorovych studied the molecular genetic basis for periodontitis development in dental patients and showed that the IL-4 gene polymorphism is one of the predictors of chronic generalized periodontitis, which was associated with a dense mononuclear inflammatory infiltrate, represented by CD4, CD8, CD20 T lymphocytes combined with a large number of CD45RO memory $T$ lymphocytes, CD68 macrophages and intensive neutrophilic infiltration [24].

However, a part of the paradontium is periodontal tissue, which in left untreated dental caries may develop an inflammatory complication such as periodontitis. On the one hand, it independently contributes to various malocclusions that, on the other hand, could be a negative consequence of being edentulous after periodontitis-related dental extraction when myodynamics is disturbed. It was demonstrated that complications of temporary teeth caries were found in more than $2 / 3$ of children and it was the leading cause of defects in the dentition (16.3 $\pm 3.6 \%$ of cases). Early tooth loss and related defects resulted in various dental anomalies in $61.7 \pm 4.8 \%$ of children [25]

The work of $A$. Z. Isamulaeva et al. covers the influence of genetic polymorphisms on the grade of inflammation, which is a promising direction for early diagnosis, comprehensive assessment of dental status in somatic patients with damage to dental hard tissues, parodontium and oral mucous membranes and the rationale for new therapeutic and preventive measures [26].

Furthermore, modern scientific studies have confirmed that the IL-4 gene polymorphism influence IL-4 and other cytokines production regulating immune responses that directly associated with caries and periodontitis development [27-29].

At the same time, the $\mathrm{T}$ allele $(\mathrm{OR}=1.2,95 \%$ $\mathrm{Cl}=1.02-1.42, \mathrm{P}=0.03)$ and the $\mathrm{T} / \mathrm{T}$ genotype $(\mathrm{OR}=1.68$, $95 \% \mathrm{Cl}=1.05-2.67, \mathrm{P}=0.03)$ of the IL-4 gene $(\mathrm{C}-590 \mathrm{~T})$ were associated with periodontitis in whites, and only the $\mathrm{T} / \mathrm{T}$ genotype was associated with periodontitis in Caucasians ( $\mathrm{T} / \mathrm{T}$ vs $\mathrm{C} / \mathrm{T}$ : OR $=1.75,95 \% \mathrm{Cl}=1.10-2.78, \mathrm{P}=0.02$ ) $[30,31]$. These data confirm, on the one hand, that the genotype frequencies in studied polymorphism of the IL-4 gene are varied among different populations; on the other hand, it is the basis of a personalized approach to patients and long-term treatment programs implementation.

Of great interest is the wide range of studies devoted to determining the role of SNP (C589T, rs2243250) of the IL-4 gene in disease occurrence.

Thus, the T allele frequency and the homozygous $T / T$ genotype prevailed in children with acute respiratory tract infections (pneumonia, brochiolitis) living in Egypt $(\mathrm{OR}=1.3 ; 95 \% \mathrm{Cl}=1.07-1.56, \mathrm{P}<0.01$ and $\mathrm{OR}=2.0$; $95 \% \mathrm{Cl}=1.38-2.96$, respectively) [32]. In patients with whooping cough, the homozygous T/T genotype (C589T) of the IL-4 gene frequency was higher than in healthy ones, and more than half of patients suffering from pyelonephritis $(52.7 \%)$ were carriers of the heterozygous $\mathrm{C} / \mathrm{T}$ variant of this gene polymorphic region [33,34].

Chronic hepatitis $\mathrm{C}$ patients with the homozygous $\mathrm{T} / \mathrm{T}$ genotype (C-589T) of the IL-4 gene showed more pronounced fibrous changes in the liver than the homozygous $\mathrm{C} / \mathrm{C}$ genotype carriers $(P<0.01)$ [35]. In patients with ischemic heart disease and coronary atherosclerosis, the C589T frequencies of the IL-4 genotype $(P=0.04$; $\mathrm{OR}=4.09)$ and 589T alleles $(P=0.04 ; \mathrm{OR}=2.45)$ were statistically significantly increased [36]. 
Scientists also took into account the possible risk of developing oncopathology associated with IL-4 genotypes and different sensitivity to chemotherapy for malignant tumors of the female reproductive organs, as well as for breast cancer $[37,38]$.

Comparison of our study results with scientific literature data has proved different effects of the studied mutations of the IL-4 gene on the peculiar features of associative prognostic links with various diseases, which in the long term justifies the need for further research in this area.

\section{Conclusions}

1. The polymorphism of the interleukin-4 gene C-589T, rs2243250) has been investigated for the first time in children with respiratory forms of allergy (bronchial asthma and allergic rhinitis) and with isolated or allergic rhinitis-induced comorbid malocclusion living in the city of Zaporizhzhia.

2. The $C / C-C / T-T / T$ genotype frequencies have been calculated in children: with bronchial asthma $69.66 \%-22.47 \%-7.87 \%$; with allergic rhinitis $58.06 \%-38.71 \%-3.23 \%$; allergic rhinitis with distal occlusion $-62.96 \%-29.63 \%-7.40 \%$ of the examined cases, which were matched their frequency in European and South Asian populations.

3. The $\mathrm{C} / \mathrm{C}-\mathrm{C} / \mathrm{T}-\mathrm{T} / \mathrm{T}$ genotypes in children with malocclusion had the following distribution: $34.78 \%-60.87 \%-$ $4.35 \%$ of the examined cases, and the heterozygous $\mathrm{C} / \mathrm{T}$ genotype prevalence indicated the presence of genetic features of distal occlusion phenotype formation.

4. The inheritance models analysis showed that the $\mathrm{C} / \mathrm{C}$ genotype of the interleukin-4 gene (C-589T, rs2243250) was associated with bronchial asthma (OR $=4.31 ; 95 \%$ $\mathrm{Cl}=1.63-11.36 ; \mathrm{P}=0.002)$ and allergic rhinitis $(\mathrm{OR}=4.32$ : $95 \% \mathrm{Cl}=1.04-7.81 ; \mathrm{P}=0.04)$ in comparison with the fact that the $C / T+T / T$ genotype indicated a predisposition to malocclusion development.

Prospects for further researches. In the future, we will focus on the analysis of presented genotypes frequency depending on the severity, stage, clinical and laboratory features of these diseases course.

\section{Funding}

The study presented is a fragment of the scientific and research work of Zaporizhzhia State Medical University: “Optimization of differential diagnostics and treatment of allergic and other diseases in children of different ages", state registration number 0118U004254 (2018-2022).

Conflicts of interest: authors have no conflict of interest to declare. Конфлікт інтересів: віАсутній.

Надійшла Ао редакції / Received: 28.05.2019

Після Аоопрацювання / Revised: 16.07.2019

Прийнято Ао Аруку / Accepted: 01.08.2019

Information about authors:

Shumna T. Ye., MD, PhD, DSc, Professor of the Faculty Pediatry Department, Zaporizhzhia State Medical University, Ukraine. Fedosieieva O. S., MD, Postgraduate student, Department of Faculty Pediatry, Zaporizhzhia State Medical University, Ukraine.
Zinchenko T. P., MD, Assistant of the Department of Therapeutic, Orthopedic and Pediatric Dentistry, Zaporizhzhia State Medical University, Ukraine.

Nedelska S. M., MD, PhD, DSc, Professor, Department of Faculty Pediatry, Zaporizhzhia State Medical University, Ukraine.

Voznyi O.V., MD, PhD, DSc, Head of the Department of Therapeutic, Orthopedic and Pediatric Dentistry, Zaporizhzhia State Medical University, Ukraine.

Kamyshnyi O. M., MD, PhD, DSc, Professor, Head of

the Microbiology, Virology and Immunology Department, Head of the Molecular-Genetic Research Division of the Medical and Laboratory Center, Zaporizhzhia State Medical University, Ukraine.

\section{Відомості про авторів:}

Шумна Т. Є., А-р меА. наук, професор каф. факультетської пеАіатрії, Запорізький Аержавний медичний університет, україна.

Федосєєва О. С., аспірант каф. факультетської педіатрії, Запорізький Аержавний медичний університет, Україна. Зінченко Т. П., асистент каф. терапевтичної, ортопедичної та Аитячої стоматології, Запорізький державний меАичний університет, Україна.

Недельська С. М., А-р меА. наук, професор,

зав. каф. факультетської педіатрії, Запорізький Аержавний медичний університет, Україна.

Возний О. В., А-р меА. наук, Аоцент, зав. каф. терапевтичної, ортопедичної та Аитячої стоматології, Запорізький Аержавний меАичний університет, Україна.

Камишний О. М., А-р меА. наук, професор,

зав. каф. мікробіології, вірусології і імунології, керівник відАілу молекулярно-генетичних АосліАжень навчального меАиколабораторного центру, Запорізький Аержавний медичний університет, Україна.

\section{Сведения об авторах:}

Шумная Т. Е., А-р меА. наук, профессор каф. факультетской педиатрии, Запорожский госуАарственный меАицинский университет, Украина.

Федосеева Е. С., аспирант каф. факультетской педиатрии, Запорожский государственный медицинский университет, Украина;

Зинченко Т. П., ассистент каф. терапевтической, ортопедической и Аетской стоматологии, Запорожский государственный меАицинский университет, Украина. Недельская С. Н., А-р меА. наук, профессор, зав. каф. факультетской педиатрии, Запорожский государственный медицинский университет, Украина. Возный А. В., А-р меА. наук, Аоцент, зав. каф. терапевтической, ортопеАической и Аетской стоматологии, Запорожский государственный медицинский университет, Украина. Камышный А. М., А-р меА. наук, профессор, зав. каф. микробиологии, вирусологии и иммунологии, руководитель отАела молекулярно-генетических исслеАований учебного медико-лабораторного центра, Запорожский государственный медицинский университет, Украина.

\section{References}

[1] Besh, L. V., Lasytsia, T. S., \& Besh, O. M. (2017). Bronkhialna astma $\vee$ praktytsi simeinoho likaria: suchasni standarty bazysnoi farmakoterapii [Bronchial asthma in family physician practice: current standards of basic pharmacotherapy]. Allergy in a child, 21/22, 8-10. [in Ukrainian].

[2] Caniatti, M., Marchioro, A., Guilherme, A., \& Tsuneto, L. (2014). Association of Cytokines in Individuals Sensitive and Insensitive to Dust Mites in a Brazilian Population. PLOS ONE, 9(9), e107921. doi: 10.1371/ journal.pone.0107921

[3] Christiansen, E., Kjaer, H., Eller, E., Bindslev-Jensen, C., Høst, A. Mortz, C., \& Halken, S. (2016). The prevalence of atopic diseases and the patterns of sensitization in adolescence. Pediatric Allergy And Immunology, 27(8), 847-853. doi: 10.1111/pai.12650

[4] Jacob, L., Keil, T., \& Kostev, K. (2016). Comorbid disorders associated with asthma in children in Germany - National analysis of pediatric primary care data. Pediatric Allergy And Immunology, 27(8), 861-866. doi: $10.1111 /$ pai.12656 
[5] Langdon, C., Guilemany, J., Valls, M., Alobid, I., Bartra, J., \& Dávila, I. et al. (2016). Allergic rhinitis causes loss of smell in children: The OLFAPEDRIAL study. Pediatric Allergy And Immunology, 27(8), 867870. doi: 10.1111/pai.12655

[6] Shamsidinov, A. T., Fajzov, K. S., Tanzhiholov, U. H., \& Ismoilov F. N. (2016). Sistema rannego vyjavlenija i reabilitacii detej i podrostkov goroda Dushanbe s zubocheljustnymi anomalijami [System for early detection and rehabilitation of children and adolescents with dentoalveolar anomalies in Dushanbe]. Herald of institute of postgraduate education in health sphere, 1. Retrieved from http://www.vestnik-ipovszrt.tj/?p=2315. [in Russian].

[7] Shamov, S. M. (2013). Vzaimosvjaz obshhesomaticheskoj patologi i zubocheljustnyh anomalij u detej i podrostkov Respubliki Dagestan [The relationship between somatic pathology and in children and adolescents in Dagestan]. Kuban Scientific Medical Bulletin, 6(141), 193-195. [in Russian]

[8] Attia, M., \& Saber, H. (2014). Role played by T-helper 2 in resetting the cytokine balance in allergic patients. The Egyptian Journal Of Internal Medicine, 26(3), 124-129. doi: 10.4103/1110-7782.145311

[9] Puhlik, B. M. (2017). Problemy nasledstvennosti v vozniknovenii allergicheskih zabolevanij [Heredity problems in the occurrence of allergic diseases]. Klinichna immunolohiia. Alerholohiia. Infektolohiia, 1(98), 29-32. Retrieved from https://kiai.com.ua/ru-issue-article-1389/ Problemy-nasledstvennosti-v-vozniknovenii-allergicheskih-zabolevaniy. [in Russian].

[10] Golovatjuk, E. P. (2017). Rol polimorfizmov genov IL-4 i IL-17 v privychnom nevynashivanii beremennosti, nastupivshej v ciklah VRT [Role of gene polymorphism of il-4 and il-17 in recurrent miscarriage, came in art cycles]. Reproductive Endocrinology, 1(33),28-31. [in Russian].

[11] Ensembl. Retrieved from http://www.ensembl.org/index.html.

[12] Ivanova, V. B. (2017). Associacii polimorfnyh genov immunnogo otveta so stepenju tjazhesti i urovnem kontrolja atopicheskoj bronhialnoj astmy (Dis. magister.). [Associations of polymorphic genes of the immune response with the severity and level of control of atopic bronchial asthma. Mast. diss.]. Krasnoyarsk. Retrieved from http://elib.sfu-kras. ru/handle/2311/69113. [in Russian].

[13] Ramphul, K., Lv, J., Hua, L., Liu, Q., Fang, D., \& Ji, R. et al. (2014). Single nucleotide polymorphisms predisposing to asthma in children of Mauritian Indian and Chinese Han ethnicity. Brazilian Journal Of Medical And Biological Research, 47(5), 394-397. doi: 10.1590/1414$431 \times 20143751$

[14] Gureva, L. L. (2015). Prognozirovanie kontrolja atopicheskoj bronhialnoj astmy v detskom vozraste. (Avtoref. dis... dok. med. nauk). [Prediction of childhood atopic asthma control]. (Extended abstract of candidate's thesis). Samara. [in Russian].

[15] Smolnikova, M. V., Frejdin, M. B., \& Smirnova, S. B. (2017). Geny citokinov kak geneticheskie markery atopicheskoj bronhialnoj astmy s kontroliruemym i nekontroliruemym techeniem [Cytokine genes as genetic markers of controlled and uncontrolled atopic bronchial asthma] Medical Immunology (Russia), 19(5), 605-614. doi: 10.15789/15630625-2017-5-605-614 [in Russian].

[16] Kostina, E. M., Molotilov, B. A., Levashova, O. A., \& Osipova, M. V. (2013). Izuchenie polimorfizma genov citokinov IL-4, IL-10, IL-17A i TNFA u bolnyh s infekcionno-zavisimoj bronhialnoj astmoj [The study of polymorphism of cytokine genes IL-4, IL-10, IL-17A and TNFA in patients with infectious dependent bronchial asthma]. Immunopathology, allergology, infectology, 1, 53-58. [in Russian]

[17] Hotko, E. A., \& Taganovich, A. D. (2016). Polimorfizm genov receptorov $i$ ih ligandov pri hronicheskoj obstruktivnoj bolezni legkih [Gene polymorphism of receptors and their ligands in chronic obstructive pulmonary disease]. Medical Journal, 3, 36-42. [in Russian].

[18] Akparova, A. Ju., Bersimbaj, R. I., Bekmanov, B. O., Eshhzhanov, T. E. \& Abishev, M. T. (2012). Rol genov citokinov IL-4 i TNF-A v razvitii predraspolozhennosti $\mathrm{k}$ bronhialnoj astme i hronicheskoj obstruktivnoj bolezni legkih [The role of the cytokine genes IL4 and TNF-a in the development of a predisposition to bronchial asthma and chronic obstructive pulmonary disease]. Molecular and geneticresearchmethods in medicine and biology. Proceedings of the International Scientific and Practical Conference. (pp. 15-22). Karaganda. [in Russian].

[19] Kuzmina, L. P., Hotuleva, A. G., Anohin, N. N., \& Anvarul N. A. (2018). Geneticheskij polimorfizm protivovospalitelnyh citokinov v ocenke riska razvitija i prognoza techenija professionalnoj bronholegochnoj patologii [Genetic polymorphism of anti-inflammatory cytokines in assessing developmental risk and prognosis of the course of occupational bronchopulmonary pathology]. Health and the environment. Proceedings of the International Scientific and Practical Conference. (Vol. 1. pp. 157-158). Minsk. [in Russian].

[20] Movahedi, M., Amirzargar, A., Nasiri, R., Hirbod-Mobarakeh, A., Farhadi, E., \& Tavakol, M. et al. (2013). Gene polymorphisms of Interleukin-4 in allergic rhinitis and its association with clinical phenotypes. American Journal Of Otolaryngology, 34(6), 676-681. doi: 10.1016/j. amjoto.2013.05.002
[21] Korzycka-Zaborowska, B., Zielińska-Bliźniewska, H., Zaborowski, A., \& Olszewski, J. (2015). Association of -590 C/T II-4 Gene Promoter Polymorphism With Atopy in Polish Patients With Allergic Rhinitis. Allergy Disorders \& Therapy, 2(1), 1-3. doi: 10.24966/ adt-749x/100004

[22] Li, Z., Yin, L., Wang, H., \& Liu, L. (2014). Association between promoter polymorphisms of interleukin- 4 gene and allergic rhinitis risk: a meta-analysis. Journal Of Huazhong University Of Science And Technology [Medical Sciences], 34(3), 306-313. doi: 10.1007/ s11596-014-1275-3

[23] Micheal, S., Minhas, K., Ishaque, M., Ahmed, F., Ahmed, A. (2013). IL-4 gene polymorphisms and their association with atopic asthma and allergic rhinitis in Pakistani patients. Journal of Investigational Allergology and Clinical Immunology, 23(2),107-111.

[24] Grigorovich, Je. Sh. (2016). Hronicheskij generalizovannyj parodontit: kliniko-morfologicheskie i molekuljarno-geneticheskie osnovy geterogennosti zabolevanija, obosnovanie prognoza i personifikacija terapi (Dis... dokt. med. nauk.). [Chronic generalized periodontitis: clinical, morphological and molecular genetic foundations of disease heterogeneity, substantiation of prognosis and personification of therapy. Dr. med. sci. diss.]. Omsk. [in Russian].

[25] Jahina, Z. H., Shirjak, T. Ju., \& Kamaldinova, A. R. (2018). Vlijanie ranne poteri zubov na formirovanie zubocheljustnyh anomalij [Effect of early loss of teeth on formacion of dental anomalies]. Modern problems of science and education, 2. Retrieved from http://www.science-education. ru/ru/article/view?id=27536. [in Russian].

[26] Isamulaeva, A. Z., Spicyna, A. V., Magomedov, Sh. Sh., Shatueva, S. Z. \& Isamulaeva, A. I. (2014). Znachimost citokinovoj reguljacii v patogeneze zabolevanij polosti rta [The significance of cytokine regulation in the pathogenesis of oral diseases]. Modern problems of science and education, 6. Retrieved from http://www.science-education.ru/ru/article/ view?id=15411. [in Russian].

[27] Bartova, J., Borilova Linhartova, P., Podzimek, S., Janatova, T., Svobodova, K., \& Fassmann, A. et al. (2014). The Effect of IL-4 Gene Polymorphisms on Cytokine Production in Patients with Chronic Periodontitis and in Healthy Controls. Mediators Of Inflammation, 1-11. doi: $10.1155 / 2014 / 185757$

[28] Anovazzi, G., Medeiros, M., Pigossi, S., Finoti, L., Mayer, M., \& Rossa, C. et al. (2017). Functional Haplotypes in Interleukin 4 Gene Associated with Periodontitis. PLOS ONE, 12(1), e0169870. doi: 10.1371/ journal.pone. 0169870

[29] Hejgetjan, A. V., Bragin, E. A., Maksjukov, S. Ju., Labushkina, A. V. Alutina Je. L., \& Harseeva, G. G. (2015). Immunologicheskie pokazateli u bolnyh s kariesom kontaktnyh poverhnostej bokovyh zubov [The immunologic indicators in patients withcaries of contact surfaces]. Russian Clinical Laboratory Diagnostics, 60(8), 52-54. [in Russian].

[30] Yan, Y., Weng, H., Shen, Z., Wu, L., \& Zeng, X. (2014). Association Between Interleukin-4 Gene - $590 \mathrm{C} / \mathrm{T},-33 \mathrm{C} / \mathrm{T}$, and 70-Base-Pair Polymorphisms and Periodontitis Susceptibility: A Meta-Analysis. Journal Of Periodontology, 85(11), e354-362. doi: 10.1902/jop.2014.140317

[31] JIA, Xaowei, MA, Yan, ZENG, Xiantao, YUAN, Yadi, LIN, Yingmei, \& SHAO, Jun et al. (2017). Association between -590C/T polymorphisms of interleukin-4 gene and periodontitis: A meta-analysis. Journal of Prevention and Treatment For Stomatological Diseases. 25(6), 354-359. doi: 10.12016/j.issn.2096-1456.2017.06.003

[32] Emam, A., Shehab, M., Allah, M., Elkoumi, M., Abdelaal, N., \& Mosabah, A. et al. (2019). Interleukin-4 -590C/T gene polymorphism in Egyptian children with acute lower respiratory infection: A multicenter study. Pediatric Pulmonology, 54(3), 297-302. doi: 10.1002/ ppul.24235

[33] Epifanceva, N. V. (2011). Rol polimorfizma genov IL-4 (S589T), IL-10 (S592A, G1082A, S819T) i FNOa (G308A) v patogeneze kokljusha $u$ detej. Dis ...kand. med. nauk [The role of IL-4 (C589T), IL-10 (C592A, G1082A, C819T) and TNFa (G308A) gene polymorphism in the pathogenesis of pertussis in children. Dr. med. sci. diss.]. Chita. [in Russian].

[34] Bataeva, E. P. (2014). Vlijanie polimorfizmov genov II-4 (S589T) i TNFa (G308A) na soderzhanie citokinov u detej pri pielonefritah [Influence polymorphism of genes IL-4 (C589T) and TNFa (G308A) on content of cytokine in children with pyelonephritis]. Far East Medical Journal, 1, 74-78. [in Russian].

[35] Usychenko, E. N., Usychenko, E. M., \& Bazhora, Ju. I. (2017). Sostojanie immunnogo statusa i polimorfizm genov citokinov IL-10, IL-4 TNF u pacientov s hronicheskim gepatitom S v zavisimosti ot stepen fibroza [Immune status and gene polymorphism of cytokines IL-10, IL-4, TNF in patients with chronic hepatitis $C$ depending on the degree of fibrosis]. Vestnik Of Vitebsk State Medical University, 16(1), 50-58. doi: 10.22263/2312-4156.2017.1.50 [in Russian].

[36] Shumilov, D. S., Tuguz, A. R., Smolkov, I. V., Tatarkova, E. A., Muzhenja, D. V., \& Ashkanova, T. M. et al. (2017). Polimorfizmy genov osnovnyh pro- i protivovospalitelnyh citokinov: IL-1 $\beta$ (T511C, 
RS16944), TNF- $\alpha$ (G308A, RS1800629), IL-4 (C589T, RS2243250) pri koronarnom ateroskleroze [Gene polymorphisms of the main pro- and anti-inflammatory cytokines: IL-1 $\beta$ (T511C, RS16944), TNF- $\alpha$ (G308A, RS1800629), IL-4 (C589T, RS2243250) in coronary atherosclerosis]. The Bulletin of the Adyghe State University: Internet Scientific Journal, 1(196), 41-46. [in Russian].

[37] Puzyreva, L. V., \& Safonov, A. D. (2016). Geneticheskij polimorfizm citokinov: proshloe i budushhee [Cytokines genetic polymorphism: the past and the future]. Russian Journal of Infection and Immunity, 6(2), 103-108. doi: 10.15789/2220-7619-2016-2-103-108 [in Russian].

[38] Anohina, E. N., Tuguz, A. R., Rudenko, K. A., \& Muzhenja, D. V. (2014). Associacija polimorfizmov genov IL-4, IL-2 so zlokachestvennymi novoobrazovanijami zhenskih reproduktivnyh organov [Association of $\mathrm{IL}-4$ and IL-2 gene polymorphisms with the malignant growths of female reproductive organs]. The Bulletin of the Adyghe State University: Internet Scientific Journal, 1(133), 51-55. [in Russian]. 